\title{
DAKWAH SOSIAL EKONOMI DALAM PANDANGAN DAWAM RAHARDJO
}

\author{
Ma'mun Efendi Nur \\ Universitas Nahdlatul Ulama Surakarta \\ Email: efmamun@gmail.com
}

\begin{abstract}
Abstrak
Islam is a humanism, a religion that is very concerned with human being as a center destination. This characteristic of Islam brings the consequence that this perfect religion is very big role for human, not only regulate and contain messages that must be implemented in vertical line to God, even role to regulate social life - relative horizontal - as well as other fields such as social, economy, politics, health, culture and so on. Dawam Rahardjo, one of the leading figures of Islamic and Modern Economics, has a view and activity in the field of social economic transformation of dakwah focused on four points (Islamic Economy, Main Society, Zakat and Islamic Self-Help and Work Ethic in Islam), each peeled deeply and applicative, which is his view and experience. Nevertheless each view is inseparable from the advantages and disadvantages
\end{abstract}

Islam adalah sebuah humanisme, yaitu agama yang sangat mementingkan manusia sebagai tujuan sentra. Karakteristik Islam tersebut membawa konsekuensi bahwa agama tersempurna ini sangat besar peranannya bagi manusia, Tidak hanya mengatur dan mengandung pesan-pesan yang harus dilaksanakan dalam garis vertikal kepada Tuhan, bahkan berperan mengatur kehidupan sosial -horisontal relative- serta bidang lain misalnya sosial, ekonomi, politik, kesehatan, budaya dan sebagainya. Dawam Rahardjo salah satu tokoh Ekonomi Islam dan Modern memiliki pandangan dan aktifitas dalam bidang dakwah transformasi sosial ekonomi terfokus pada empat poin (Ekonomi Islam, Masyarakat Utama, Zakat dan Pengembangan Swadaya Umat Islam dan Etos Kerja dalam Islam), masing-masing dikupas secara menadalam dan aplikatif, yang merupakan pandangan dan pengalamannya. Namun demikian setiap pandangan tidak terlepas dari kelebihan dan kekurangan.

Kata kunci : Dakwah, Raharjo, Sosial Ekonomi 


\section{A. Pendahuluan}

Islam adalah sebuah humanis, yaitu agama yang sangat mementingkan manusia sebagai tujuan sentral. ${ }^{1}$ Selain itu juga sebagai agama yang kekal dan universal sehingga pemahaman kaum Muslim terhadapnya tidak boleh dibatasi hanya kepada pengertian formal dan legalnya, khususnya yang dibangun dalam konteks ruang dan waktu tertentu. Melainkan, pemahaman itu harus didasarkan kepada penafsiran yang menyeluruh, yang menerapkan petunjuk tekstual dan doktrinalnya ke dalam situasi dan konteks kontemporernya. ${ }^{2}$

Karakteristik Islam tersebut membawa konsekuensi bahwa agama tersempurna ini sangat besar peranannya bagi manusia, Tidak hanya mengatur dan mengandung pesan-pesan yang harus dilaksanakan dalam garis vertikal kepada Tuhan, bahkan berperan mengatur kehidupan sosial horisontal relative- serta bidang lain misalnya sosial, ekonomi, politik, kesehatan, budaya dan sebagainya.

Luasnya kiprah Islam humanis dalam membangun peradaban manusia ke arah lebih positif sejalan bahwa agama ini memiliki perwujudan dalam dua bentuk. Pertama, adalah Islam sebagai sistem keagamaan transendental yang ideal. Islam dalam wujud ini dicerminkan oleh ilmu-ilmu ke-Islaman, sebagai hasil interpretasi terhadap aI-Qur'an dan teladan Nabi saw oleh para ulama dan cendekiawan. Kedua, Islam sebagai realitas sejarah. Wujud dari Islam seperti itu dicerminkan oleh kebudayaan, peradaban dan masyarakat Islam, yang menurut Dawam Rahardjo antara keduanya terdapat gap, yaitu Islam yang ideal dan historis yang telah dibentuk juga oleh faktor-faktor sosial, ekonomi, politik dan proses kesejarahan. ${ }^{3}$

Terciptanya masyarakat madani yang sering pula disebut sebagai civil society merupakan kumpulan orang yang memiliki kesamaan budaya (a group of people who share a common culture). Penjelasan ini adalah jabaran terhadap konsep khoiru ummah pada Q.S Ali Imron ayat 110, yang artinya "Kamu adalah umat yang terbaik yang dilahirkan untuk manusia, menyuruh kepada yang ma'ruf dan mencegah dari yang munkar dan beriman kepada Allah. Sekiranya ahli Kitab beriman, tentulah itu lebih baik bagi mereka, diantara mereka ada yang beriman dan kebanyakan

1 Kuntowijovo, Pradigma Islam Interpretasi Untuk Aksi (Bandung: Mizán. 1991) hlm. 167

2 Bahtiar Effendy, Islam dan Negara Transformasi Pemikiran dan Praktik Politik Islam di Indonesia, (Jakarta: PT. Raja Grafindo Persada, 1998) hlm. 134

3Jurnal Ulumul Quran,vol. III, No: 4 Tahun 992 hlm. 49 
mereka adalah orang-orang yang fasiq".. Budaya itu adalah berorientasi terhadap al-khoir, memiliki mekanisme amar ma'ruf nahi munkar, aturan, tatanan dan pemerintahan yang adil serta beriman kepada Allah. ${ }^{5}$

Seorang Dawam Rahardjo meskipun berbasis politis namun terdapat unsur amar ma'ruf nahi munkar - term ini telah menjadi jargon politik dengan pendekatan ekonomi dan sosial. Sebagaimana diketahui bahwa unsur ini merupakan sebuah dakwah/seruan untuk mengajak masyarakat ke jalan Allah. Pendekatan yang dilakukan oleh Dawam Rahardjo dengan menyandarkan terhadap pesan-pesan dengan landasan hukum Islam sesuai dengan karakteristik aliran transformasi sosial yang menekankan terhadap hubungan yang harmonis antara Islam dan negara dengan memanfaatkan lembaga-lembaga kemasyarakatan. Bahkan teori ekonomi Dawam Rahardjo menyangkut sistem moral dan fondasi ekonomi dengan menawarkan nilai-nilai Islam, contohnya konsep ZIS (Zakat, Infaq Shadaqoh), agar dapat diaplikasikan dalam kehidupan umat Islam.

Dakwah sebagai langkah menuju transformasi masyarakat tidak hanya berorientasi terhadap peningkatan hubungan vertikal kepada Allah semata melainkan juga memupuk kualitas diri sebagai individu dalam menuju pembentukan pemberdayaan umat. Karena sebagai makhluk Allah yang dipenuhi dengan rasio serta akhlak, manusia haruslah mampu melangkah menuju proses perubahan sebagai natural of law apalagi dalil normatif sendiri menegaskan bahwa Allah tidak akan merubah kondisi umat bila makhluk itu sendiri tidak memiliki upaya menuju perubahan ke arah yang lebih maju.

Pemberdayaan ekonomi umat mengandung tiga misi. Pertama, misi pembangunan ekonomi dan bisnis yang berpedoman pada ukuran-ukuran ekonomi dan bisnis yang lazim dan universal. Kedua, pelaksanaan etika dan ketentuan hukum syariah yang harus menjadi ciri kegiatan ekonomi umat Islam. Ketiga, membangun kekuatan ekonomi umat Islam sehingga menjadi sumber dana pendukung dakwah Islam yang dapat ditarik melalui zakat, infaq, sodaqoh, wakaf serta menjadi bagian dari pilar perekonomian Indonesia. 6

Sedangkan transformasi (perubahan) sosial berlangsung sangat kompleks. Agama seringkali disebut sebagai faktor pendorong terjadinya perubahan ke arah positif. ini merupakan indikasi urgensi agama bagi

\footnotetext{
${ }^{4}$ Depag. Al Quran dan Terjemahan, (Jakarta, 1974), hlm. 94

5 M. Dawam Rahardjo, Masyarakat Madani: Agama, Kelas Menengah, dan Perubahan Sosial, (Jakarta: LP3ES, 1999) him. 122

6 M. Dawam Rahardjo, Islam dan Transformasi Sosial Ekonomi (Yogyakarta: Pustaka Pelajar, 1999) hlm. 359
} 
masyarakat yang menimbulkan keterikatan terhadap religious values. Sikap semacam ini akan mendorong terhadap pembentukan perilaku-perilaku keberagamaan yang lebih mendalam pada diri masing-masing individu. Namun disisi lain agama terkadang juga disebut sebagai faktor penghambat terhadap perubahan. ini disebabkan agama sebagai way of life memiliki aturan-aturan yang tersimbolkan dan juga terprofankan. Sehingga ketika proses perubahan berjalan dan ternyata tidak sesuai dengan simbol simbol tersebut maka secara otomatis akan terjadi penolakan.

Berdasarkan pada kenyataan bahwa agama selalu dijadikan sebagai way of life, maka menrik untuk melihat pemikiran Dawam Raharjo dalam dakwah, terkait dengan sosial ekonomi. Proses menuju perubahan memerlukan beberapa teori yang berperan sebagai acuan dan sasaran serta strategi menuju arah yang lebih kondusif. Untuk itulah pemikiranpemikiran Dawam Rahardjo dapat dijadikan sebagai salah satu alternatif untuk dijadikan referensi dan acuan dalam pembangunan yang berlandaskan nilai-nilai Islami karena hasil studi dan risetnya masih sangat relevan dengan kebutuhan umat.

\section{B. Pengertian Dakwah}

Kajian mengenai dakwah pernah dibicarakan dalam simposium maupun seminar-seminar oleh para cendekiawan muslim yang bertujuan untuk mencari formulasi baru tentang term dakwah. Upaya-upaya untuk memformulasikan term dakwah tersebut karena berangkat dari kesadaran bahwa pemikiran tentang dakwah yang pada saat itu berkembang masih mengalami kesenjangan yang perlu dijembatani.

Kesenjangan pokok yang perlu dijembatani, menurut Amrullah Ahmad adalah: Pertama, kesenjangan yang berasal dari cara memberikan pengertian dakwah yang mempengaruhi tradisi dakwah di Indonesia. Kedua; kesenjangan yang disebabkan tiadanya kerangka keilmuan tentang dakwah yang mampu memberikan penjelasan tentang kenyataan dakwah Islam yang berarti merupakan kesenjangan antara teori dan praktek (realita). ${ }^{7}$ Dengan adanya dua kesenjangan pokok tersebut tidak menutup kemungkinan pemahaman masyarakat mengenai dakwah masih bersifat konvensional. Bahwa dakwah masih dianggap sebagai kegiatan moral keagamaan antara penyampai risalah dan objeknya. Meskipun zaman

7 Amrullah Ahmad (Ed), Dakwah Islam dan Perubahan Sosial, (Yogyakarta: PLP2M, 1983), hlm. 5 
semakin berkembang dan dakwah dapat saja dimasukkan dalam seluruh sendi kehidupan manusia.

Terlepas dari kenyataan di atas, dibawah ini akan dikemukakan berbagai pendapat para ilmuwan muslim mengenai terminologi dakwah, tetapi sebelum membahas lebih lanjut, terlebih dahulu akan dibahas pengertian etimologinya. Arti Dakwah ditinjau dari segi etimologi (bahasa) berarti panggilan, ajakan, dan seruan. Dalam ilmu tata bahasa Arab kata "dakwah" berbentuk isim masdar yang berasal dari memanggil, mengajak, atau menyeru. ${ }^{8}$ Kata tersebut dapat kita jumpai dalam ayat al-Qur'an, seperti dalam Q:S Al Baqarah: 23 yang artinya "dan ajaklah penolong penolongmu selain Allah ...9 Dari ayat ini jelas bahwa keberadaan mengajak ini lebih ditekankan pada ajakan untuk mengerti lebih mendalam tentang kandungan Islam.

Definisi di atas merupakan makna etimologis. Berikut ini beberapa pendapat tentang dakwah dalam perspektif terminologis:

a. Amrullah Ahmad mendefinisikan dakwah yaitu:

"Hakikat dakwah Islam sendiri merupakan aktualisasi imani (teologis) yang dimanifestasikan dalam suatu system kegiatan manusia beriman dalam bidang kemasyarakatan yang dilaksanakan secara teratur untuk mempengaruhi cara merasa, berfikir, bersikap dan bertindak manusia pada dataran kenyataan, individual, dan sosio kultural dalam rangka mengusahakan terwujudnya ajaran Islam dalam semua segi kehidupan dengan menggunakan cara tertentu."10

b. Prof.H.M.Arifin,M.Ed mendefinisikan dakwah sebagai:

“......suatu kegiatan ajakan baik dalam bentuk lisan, tulisan, tingkah laku dan sebagainya yang dilakukan secara sadar dan berencana dalam usaha mempengaruhi orang lain baik secara individual maupun secara kelompok agar supaya timbul dalam dirinya suatu pengertian kesadaran, sikap penghayatan, serta pengamalan terhadap ajaran agama sebagai message yang disampaikan kepadanya dengan tanpa adanya unsur paksaan. ${ }^{11}$

${ }^{8}$ Asmuni Syukir, Dasar-Dasar Strategi Dakwah Islam, (Surabaya: A1-IkhLas, 1993), hlm. 17

9 Depag RI, Al-Qur'an dan Terjemahannya, (Jakarta: Yayasan Penyelenggara Penterjemah Al-Qur'an, 1983), hlm., 345

${ }_{10}$ Amrullah Ahmad, Dakwah Islam... Op.Cit hlm. 2

${ }^{11}$ H.M. Arifin, Psikologi Dakwah, (Jakarta: Bumi Aksara, 1993), Cet II, hlm. 6 
c. Dr.H.Hamzah Ya'qub mengartikan dakwah sebagai proses Mengajak umat manusia dengan hikmah kebijaksanaan untuk mengikuti petunjuk Allah dan Rasul-Nya. ${ }^{12}$

d. Abdul Munir Mulkhan memberikan pengertian dakwah sebagai: "Dakwah adalah aktualisasi atau realisasi salah satu fungsi kodrati seorang muslim, yaitu fungsi kerisalahan berupa proses pengkondisian agar seseorang atau masyarakat mengetahui, memahami, mengimani, dan mengamalkan Islam sebagai ajaran dan pandangan hidup."13

Dari beberapa pemikiran mengenai dakwah di atas, dapat diketahui bahwa semuanya mempunyai makna yang identik. Namun, masing-masing mempunyai penekanan yang berbeda antara satu definisi dengan lainnya. Dengan demikian, berangkat dari beberapa definisi di atas, dapat disimpulkan bahwa dakwah adalah proses penyampaian pesan-pesan Islam bagi masyarakat umum baik melalui moral, tindakan maupun simbolsimbol yang mendorong terciptanya kondisi masyarakat serta dilaksanakan tanpa adanya unsur paksaan dan dapat memanfaatkan berbagai media untuk dapat mencapai kebahagiaan dunia dan akhirat. Dengan ungkapan lain bahwa dakwah dapat berorientasi untuk merubah suatu masyarakat dari keadaan yang tidak atau kurang baik ke arah yang lebih baik, dari menyembah selain Allah dirubah pada keyakinan ketauhidan dan dari suasana atau kondisi lemah secara ekonomis ke arah kehidupan yang lebih berharkat dan berharga diri dan dari yang timpang secara sosial ekonomi ke arah terciptanya keadilan sosial.

\section{Landasan Dakwah}

Dari berbagai definisi mengenai kegiatan berdakwah dapat digarisbawahi bahwa ajaran untuk menyampaikan ajaran Islam tersebut merupakan suatu kewajiban, Karena merupakan suatu kewajiban maka diperlukan landasan hukum yang menegaskan dan mengungkapkan hukum dari berdakwah. Dasar hukum tersebut termaktub dalam firman Allah dan Hadits Nabi. Allah berfirman dalam al-Qur'an Surat An Nahl: 125:

Serulah ('manusia,) kepada jalan Tuhanmu dengan hikmah dan pelajaran yang baik dan bantahlah mereka dengan cara yang baik. SesungguhnyaTuhanmu Dialah yang lebih mengetahui

12 Hamzah Ya'qub, Publisistik Islam Tehnik Dakwah dan Leadership, (Yogyakarta: Bulan Bintang), 1992, hlm. 13

13 Abdul Munir Muikhan, Ideologisasi Gerakan Dakwah Episode kehidupan Al. Natsir dan Azhar Basyir, (Yogyakarta: Sipress, 1996), Cet. I hlm, 205 
tentang siapa yang tersesat dari jalan-Nya dan Dialah yang lebih mengetahui orang-orang yang mendapat petunjuk. ${ }^{14}$

Mengenal hukum berdakwah ini, terdapat perbedaan pendapat di kalangan para 'ulamâ dalam memandang konteks dakwah, yaitu, mengenai siapa yang mendapatkan kewajiban tersebut. Perbedaan tersebut muncul berdasarkan perbedaan dalam memberikan penafsiran kata "min kum" dalam surat Ali Imran ayat 104.15 'Ulamâ' kelompok pertama menafsirkan "min kum" dengan "Ii al-tabyin" atau "li al-bayanah", maksudnya, "menerangkan", sehingga merujuk pada fardhu 'ain kewajiban yang harus dijalani setiap muslim(ah). Pendapat yang diajukan kelompok ini ternyata berdasarkan Hadits Nabi:

"Dari Abu Said al-Khudni ra berkata: Saya telah mendengar Rasulullah saw., bersabda: "Siapa diantara kamu melihat kemungkaran, maka hendaklah Ia merubahnya dengan tangannya, jika tidak kuasa maka dengan lisannya, jika tidak kuasa dengan lisannya maka dengan hatinya. Yang demikian itu adalah selemah-lemahnya iman" 16

Berdasarkan hadits ini melaksanakan dakwah Islam berarti kewajiban pribadi setiap muslim mukallaf, menurut kemampuan dan sesuai kondisi, situasi, masing-masing. Sedangkan kelompok pendapat kedua menafsirkan kata "min kum" dengan "li al-tab'id" atau "sebagian", sehingga, merujuk kepada hukum fardu kifáyah (kewajiban kolektif). Pendapat kedua, menyandarkan pendapatnya kepada firman Allah surat Ali 'Imrân ayat 110, yaitu:

"Kamu adalah umat yang terbaik yang dilahirkan untuk manusia, menyuruh kepada yang ma'ruf dan mencegah dari yang mungkar dan beriman kepada Allah. ${ }^{17}$

14 Depag Rl, Op.Cit. hlm. 421

15 Aminuddin Sanwar, "Pengantar Ilmu Dakwah", (Semarang: Diktat Fakultas Dakwah IAIN Walisongo, 1987), hlm. 34-35.

16 Syaikh al-Islam Muhyiddin, Riyadh al-Shalihin, Dar al-Ihya, Indonesia, t.th., hlm. 108.

17 Departemen Agama RI., Al-Quran dan Terjemahannya, (Surabaya: CV. Jaya Sakti, 1989), hlm. 94. 
Berdasar pada ayat di atas, dapat diketahui bahwa manusia merupakan makhluk yang sempurna dan terbaik jika dibandingkan dengan makhluk lainnya. Untuk itu, dalam mempertahankan eksistensinya diperlukan dakwah sebagai proses untuk mencegah kemungkaran yang akan dilakukan oleh manusia

\section{Unsur-Unsur Dakwah}

Unsur adalah bagian yang penting dalam sesuatu hal yang harus ada untuk terwujudnya sesuatu hal tersebut.18 Unsur-unsur dakwah adalah segala aspek yang ada sangkut pautnya dengan proses pelaksanaan dakwah, dan sekaligus menyangkut tentang kelangsungannya. Banyak unsur yang perlu diperhatikan oleh para da'i.

Menurut Abdul Munir Mulkhan terdapat empat faktor penting dalam dakwah yakni:

1. Manusia penyeru dan mempunyai dakwah, yang dalam hal ini dapat dinamakan da'i, mubaligh atau juru dakwah. Semua ini di sebut Adalah orang yang melakukan dakwah, yaitu orang yang berusaha mengubah situasi kepada situasi yang sesuai dengan ketentuan-ketentuan Allah swt. baik secara individu maupun berbentuk kelompok (organisasi), sekaligus sebagai pemberi informasi dan pembawa misi. ${ }^{19}$

Penerima dakwah, yaitu seseorang manusia atau kelompok atau masyarakat banyak. Yaitu seseorang manusia atau kelompok atau rakyat banyak yang berstatus sebagai penerima ajakan dakwah, yang dalam peristilahannya sering juga disebut umat, terbagi dalam dua kategori yaitu obyek dakwah umum dan khusus. Obyek dakwah umum adalah masyarakat luas, yang mayoritas, yang awam sedangkan yang khusus adalah mereka yang karena status sosial, status ekonomi, status biologis, status rasional atau status geografiknya dapat dikelompokkan menjadi kelompok individu dengan sifat-sifat yang lebih homogen. ${ }^{20}$

2. Isi dakwah, yaitu pandangan dan tujuan hidup Islam yang meliputi amar ma'ruf nahi munkar di berbagai hidup manusia.

3. Media dakwah, yaitu alat-alat komunikasi modem sekarang ini, seperti persuratkabaran, radio, film' dan televisi. ${ }^{21}$

18 Amrullah Ahmad, Prospek Dakwah Islam dalam Masyarakat Informasi Abad ke 21, (Bandung: Remaja Rosdakarya, 1988), hlm., 21

19 H.M. Hafi Anshari, Pemahaman dan Pengalaman Dakwah, (Surabaya: Al Ikhlas, 1993), hlm, 105

${ }^{20}$ Abdul Munir Mulkhan, Op.Cit, hlm, 209

${ }^{21}$ Abdul Munir Mulkhan, Op.Cit., hlm 52 


\section{E. Dakwah Islam dan Transformasi Sosial Ekonomi}

Secara makro, sistem dakwah merupakan sub system sosio kultural dalam arti luas, sehingga analisanya tidak dapat dilepaskan dengan sub sistem ideologi, politik, pendidikan, ekonomi, ilmu, teknologi dan budaya dalam arti sempit.22 Ini berarti dakwah Islam sebagai agen perubahan sosial harus mampu menjangkau setiap persoalan yang terjadi dalam kehidupan masyarakat, termasuk dalam tatanan kehidupan ekonomi.

Eksistensi dakwah Islam dalam menghadapi masalah yang sangat riil adalah membebaskan kemiskinan. ${ }^{23}$ Kemiskinan ini timbul dikarenakan tidak meratanya pendapatan sehingga memunculkan ketidakadilan sosial. Ditambah ukuran dan kemajuan maupun keterbelakangan ditentukan oleh materi yang kemudian memunculkan kemiskinan dan kemakmuran dan tentu saja berimbas dengan penggolongan-penggolongan manusia yang dilihat secara ekonomis.

Di sinilah pentingnya peran dakwah dalam melakukan transformasi sosial ekonomi. Sebab pada dasarnya dakwah Islam merupakan aman ma'ruf nahi munkar termasuk di dalamnya membebaskan kemiskinan, ketidakadilan, dan mengupayakan masyarakat pada kehidupan ekonomi yang lebih mapan.

Lebih lanjut menurut Amrullah Achmad masalah yang harus dipecahkan adalah meningkatkan kesadaran masyarakat bahwa mewujudkan keadilan sosial dirasakan sebagai kewajiban agama. ${ }^{24}$ Apalagi dalam kerangka agama Islam upaya menciptakan pemerataan memiliki tempat tersendiri yang olehnya dianggap sebagai sikap moral yang terpuji di hadapan Allah. ${ }^{25}$

Islam adalah agama dakwah. Hal ini disebabkan karena kebenaran yang terkandung dalam ajaran Islam itu menurut kodratnya harus tersiar. Ajaran Islam adalah universal. Islam tidak membedakan warna kulit, ras dan bangsa, kedudukan sosial dan sifat-sifat insidental yang melekat pada manusia dan menyeru untuk berbakti kepada Allah Yang Maha Esa. Itulah sebabnya Islam menurut kodratnya harus tersiar dan diterima oleh pelbagai kelompok umat manusia. Kehidupan nabi Muhammad saw. sendiri yang memberikan contoh dan suri tauladan bagi dakwah Islam. ${ }^{26}$

22 Amrullah Achmad, Loc. Cit, hlm 15

23Ibid., hlm. 22

${ }^{24}$ Ibid., hlm. 23

${ }^{25}$ Ibid., hlm. 22

26 H.A. Mukti Ali, Beberapa Persoalan Agama Dewasaini, (Jakarta: Rajawali Press, 1985), hlm 71 
Selain tujuan dakwah Islam itu adalah menjadikan orang dan masyarakat itu beriman kepada Allah, jiwa bersih, diikuti dengan perbuatan-perbuatan yang sesuai dengan ucapan batinnya, dan juga untuk kepentingan bangsa, negara dan umat manusia dalam memenuhi kewajiban berbakti kepada Allah. Dakwah yang berarti menerapkan dan melaksanakan ajaran Islam dalam berbagai aspek hidup dan kehidupan menuntut kita umat Islam umumnya untuk memahami dan menggali wahyu sebagai petunjuk untuk diaplikasikan, menjawab tantangan situasi dan kondisi dalam kehidupan sehari-hari. Atas dasar inilah maka hasil dakwah Islam ialah terbinanya umat yang sadar, terhadap agamanya, bangsa dan negara diarahkan kepada transformasi yang lebih positif.

Menurut Abdul Munir Mulkhan beberapa hal yang memuat terminologi dakwah adalah:

1. Proses pengkondisian

2. Perubahan yang menumbuhkan kesadaran internal

3. Pemecahan masalah atau pemenuhan kebutuhan

Dengan mempergunakan cara pandang di atas, menurutnya dakwah tidak hanya dipandang sebagai proses komunikasi saja melainkan juga proses perubahan sosial. Dakwah merupakan suatu proses perubahan sosial apabila perubahan nilai juga terjadi pada tingkat masyarakat dimana sebagian besar anggota masyarakat bertindak berdasarkan kebenaran dan kebaikan tersebut. Pada tingkat komunitas ini, proses perubahan nilai dimungkinkan akibat interaksi sosial antar individu anggota masyarakat baik sebagai objek maupun subyek dakwah. ${ }^{27}$

Esensi dakwah dalam sistem sosio kultural adalah mengadakan dan memberikan arah perubahan, mengubah struktur masyarakat dan budaya dari kedhaliman ke arah keadilan, kebodohan, ke arah kepandaian, atau kecerdasan, kemiskinan ke arah kemakmuran, keterbelakangan ke arah kemajuan yang semuanya dalam rangka meningkatkan derajat manusia dan masyarakat ke arah puncak kemanusiaan (taqwa). ${ }^{28}$ Jelaslah bahwa dakwah tidak hanya mencakup perubahan atau transformasi nilai religius ke arah yang lebih benar namun dalam aspek-aspek kehidupan manusia seperti politik, ekonomi, pendidikan, pembangunan yang bersifat Islami. Perubahan menjadi lebih seimbang antara materiil dan spiritual.

Oleh karena perubahan sosial dan ekonomi menuju pada arah tertentu maka dakwah Islam berfungsi memberikan arah dan corak ideal tatanan masyarakat baru yang akan datang. Aktualitas dakwah berarti

\footnotetext{
${ }^{27}$ Abdul Munir Mulkan, loc.cit., hlm. 205-206.
}

${ }^{28}$ Amrullah Achmad (ed), loc.cit., hlm. 17/ 
upaya penataan masyarakat terus menerus di tengah-tengah dinamika perubahan sosial sehingga tidak ada satu sudut kehidupan-pun yang lepas dari perhatian dan penggarapannya. ${ }^{29}$ Oleh sebab itu, dakwah Islam harus mampu menyeleksi materi-materi yang relevan dengan pengembangan ekonomi Islami sehingga etos kerja manusia tidak hanya dilandaskan pada aspek materiil saja namun aspek religius memegang peranan penting dalam mengarahkan aktifitas ekonomi.

Apabila dalam proses dakwah diketemukan unsur-unsur antara lain materi atau nilai-nilai yang akan disampaikan, subyek dan obyek dakwah, media dan hal-hal yang mendukung lainnya maka dalam transformasi juga memerlukan suatu gagasan atau ide, untuk itu diperlukan tiga syarat. Pertama, ada nilai-nilai tertentu atau suatu sistem tata nilai yang ingin direalisir. Kedua, ada sekelompok manusia yang ingin mempelopori realisasi gagasan tersebut. Ketiga, ada kelompok orang besar yang ingin menikmati realisasi nilai-nilai tersebut. ${ }^{30}$

\section{F. Dawam Rahardjo dan Dakwah Sosial Ekonomi}

Sebelum mengangkat gagasan dakwah sosial ekonomi Dawam Rahardjo, kiranya perlu mengetahui sekilas sosok Dawam Rahardjo. Dia dilahirkan di Solo, pada tanggal 20 April 1942, pakar ekonom muslim ini menikmati masa kecilnya di Desa Tempursari, Solo. Di tempat kelahirannya, Dawam mendapatkan dasar-dasar pemahaman mengenai Islam. Beserta keluarganya Dawam tidak saja akrab dengan pranatapranata sosial kemasyarakatan Islam seperti pondok pesantren Jamsaren, Perguruan Al-Islam, Pesantren Krapyak atau organisasi Islam perkotaan Muhammadiyah tetapi juga dekat dengan kiai-kiai berpengaruh seperti K.H. Imam Ghozali, K.H.Ali Darokah, Ustadz Abdurrahman yang notabene adalah tokoh-tokoh yang mengajarkannya mengenai bahasa Arab, Fiqh, Tafsir, Hadist, dan Tajwid tingkat dini. ${ }^{31}$

Setelah lulus SMA Dawam melanjutkan pendidikan di Fakultas Ekonomi, Universitas Gadjah Mada yang pada akhirnya menjadikan dirinya sebagai "seseorang" yang dikenal oleh banyak kalangan. Di kota Yogyakarta ini, minatnya terhadap pemikiran-pemikiran mengenai

\footnotetext{
${ }^{29}$ Ibid

30 Padmo Wahjono, Transformasi Nilai-nilai Ideologi Bangsa, (Jakarta: Mimbar BP-7 tahun III 1986), hlm. 11

31 Bahtiar Effendi M. Dawam Rahardjo Dan Pembaharuan Pemikiran Islam: Perspektif Transformasi Sosial Ekonomi", dalam Dawam Rahardjo, Islam dan Transformasi Sosial Ekonomi, (Yogyakarta: Pustaka Pelajar, 1999), Cet I,
} 
keislaman mulai berkembang. Dawam mulai aktif sebagai anggota Himpunan Mahasiswa Islam. Wawasannya yang berkembang berdasarkan atas tiga alasan mendasar, yaitu :

Pertama, situasi sosial - keagamaan dan politik Indonesia yang sebanding dengan periode sebelumya, Indonesia pada dasawarsa 1960-an masih disibukkan oleh antagonisme ideologis dan politis antara Islam dan negara. Situasi demikian muncul antara lain karena idealisme dan aktivisme para pemikir dan praktisi politik Islam generasi pertama yang kental dengan nuansa formalistik dan legalistiknya. Kecenderungan demikian telah mendatangkan implikasi-implikasi sosial politik yang tidak menguntungkan komunitas Islam. Alasan inilah yang mendorong para generasi muda pada saat itu untuk menemukan sintesa yang memungkinkan dalam soal hubungan antara Islam politik atau negara. Dalam kerangka itulah, mereka merasa perlu melakukan kajian ulang atas posisi agama Islam dalam posisi kehidupan sosial ekonomi dan politik keseharian khususnya yang menyangkut dasar-dasar teologisnya.

Kedua, Himpunan Mahasiswa Islam Yogyakarta merupakan organisasi mahasiswa Islam yang terbesar pada waktu itu tidak kebal dari pengaruh situasional sebagaimana di atas. Sebaliknya, para aktifis HM1 justru memainkan peranan penting dalam memberikan respons terhadap situasi sosial politik Indonesia. Hal ini tampak dalam wacana yang dikembangkan oleh para tokohnya, baik yang ada di Yogyakarta maupun Jakarta, yang berusaha untuk mengaitkan Islam dengan persoalanpersoalan keseharian yang lebih empirik sifatnya. Meskipun secara keorganisasian, keharusan untuk mengembangkan dialektika pemikiran dan aktivisme baru ini tidak pernah menjadi kebijakan resmi organisasi, tetapi HMI tetap memberikan semacam institusional leverage kepada para kadernya melalui training-training yang diselenggarakannya secara periodik. ${ }^{32}$

Ketiga, aktivitas Dawam di dalam kelompok diskusi yang dipimpin Prof. Dr. Mukti Ali -limited group-. Kelompok diskusi yang dihadiri secara rutin oleh antara lain Syu'bah Asa, Syaifullah Mahyudin, Djauhari Muhsin, Kuntowijoyo, Syamsuddin Abdullab, Muin Umar, Kamal Muchtar, Simuh, di samping Djohan Effendy, Ahmad Wahib, Mansyur Hamid, dan Dawam Rahardjo sendiri terbiasa membahas masalah-masalah keagamaan, sosial,

32 Bahtiar Effendi, "M. Dawam Rahardjo Dan Pembaharuan Pemikiran Is1am Perspektif Transformasi Sosial Ekonomi”, dalam Dawam Rahardjo, Islam dan Transformasi ...., Op.Cit., hlm., hlm. xi, 
politik, dan sebagainya secara terbuka, tanpa perlu merasa takut untuk dicap telah keluar dari kaidah-kaidah religius dan teologis yang lazim. ${ }^{33}$

Ketiga faktor ini memberikan Dawam Rahardjo kesempatan untuk melihat Islam dalam konteks ke-Indonesiaan secara lebih empiris. Dawam tak lagi tertarik untuk memahami Islam dalam konteks tekstual tetapi dalam konteks persoalan yang berkembang di bumi Nusantara. Dawam pun tak lagi melihat al-Qur'an dalam perspektif ilmu tajwid saja, tetapi membacanya dan membahasakannya dalam konteks kebutuhan-kebutuhan yang lebih riil. Karenanya, ketika kebuntuan hubungan ideologis antara Islam dan negara masih saja terasakan, ia misalnya menulis dalam majalah Islam yang didirikan dan dipimpin Buya Hamka, Panji Masyarakat, tulisnya "Meskipun Islam -sebagai agama- mengandung ajaran-ajaran sosial politik, ia dalam dirinya sendiri bukanlah sebuah ideologi. Ideologi Islam (pada dasarnya) tidak pernah ada. ${ }^{34}$

Aktifitas Dawam Rahardjo tidak hanya terbatas pada LP3ES saja. Pada tahun 1978, bersama Adi Sasono, M.Amin Aziz, Abdullah Thoha dan AM. Syaefuddin mendirikan Pusat Pengembangan Agrobisnis (PPA) yang mempunyai tujuan selain untuk mengembangkan atau meningkatkan produktifitas adalah untuk menghasilkan manajemen modern yang semuanya tercakup dalam konsep agribisnis dan agroindustri. Dawam juga menjadi Direktur Utama Pusat Pengembangan Agribisnis dari tahun 1987 sampai sekarang.

Akan tetapi, posisinya sebagai aktivis Lembaga Swadaya Masyarakat (LSM mengharuskannya melangkah lebih jauh, sehingga membuat Islam tampak lebih relevan bagi kebutuhan publik sehari-hari. Dalam konteks inilah Dawam-bersama-sama dengan Sudjoko Prasodjo, Adi Sasono dan Utomo Danandjaja - memilih untuk melakukan kegiatan-kegiatan yang lebih konkrit, sebagai ekspresi dan semangat kesantriaannya di satu pihak, dan pemahamannya atas persoalan-persoalan kerakyatan di pihak lain. ${ }^{35}$

Perhatian Dawam tentang visi kemasyarakatan telah berlangsung lama. Wacana tersebut digelutinya, terutama sejak 1980-an dan LP3ES memberikan kepercayaan untuk menjabat sebagai direktur selama dua periode (1980-1986). Perhatian Dawam tentang teori negara dan masyarakat (state and society) dirangsang oleh interaksi Dawam dengan beberapa cendekiawan Asia Tenggara, terutama Prof. Rudolf S. David, dari departemen Sosiologi dari Universitas Philipina. Mereka menjadi akrab sejak bertemu di Yokohama, Jepang, ketika diundang untuk menghadiri

\footnotetext{
33Ibid, tthn. xii.

${ }^{34}$ Ibid,

${ }^{35}$ Ibid hlm., xiii.
} 
Konperensi Riset Perdamaian. Ketika itu Dawam merasa beruntung dapat berkenalan dengan beberapa tokoh dunia seperti Ivan Illich, Teotonia Dos Santos, Andre Gunder Frank dan Yoshikasu Sakamoto dari Universitas Tokyo. Menurut perkiraan Dawam, dirinya diundang dalam acara tersebut karena berkenalan dengan Prof. Sakamoto dan mempersiapkan ceramahnya yang mengesankan di LSP (Lembaga Studi Pembangunan) yang dipimpin oleh Adi Sasono. ${ }^{36}$

Setelah itu, Dawam memimpin sebuah proyek kajian Asia Tenggara yang disponsori oleh UN University yang pada waktu itu rektornya adalah Dr. Soedjatmoko yang bertemakan State and Society in The Contextof Transnationalization. Penelitian yang sama, dilakukan juga di Philipina, Singapore, Malaysia, dan Thailand selama tiga tahun. Setiap tahun Dawam dan rekan rekannya bertemu untuk melaporkan hasil penelitian. Selain itu mereka juga bertemu di seminar-seminar regional. Dari situlah Dawam menghayati persoalan mengenai Negara dan masyarakat. Dalam proyek tersebut, Dawam mengajak teman-temannya dari Indonesia seperti Arief Budiman, Daniel Dhakidae, Kuntowidjoyo, Farchan Bulkin, Kartjono, Ignas Kleden, dan dua teman muda Dawam yakni Fachry Ali dan Hadimulyo. ${ }^{37}$

Karya-karya Dawam Rahardjo banyak yang sudah diterbitkan. Karyanya tersebut berupa esai, artikel dan buku. Di antara karya-karya beliau yang berbentuk buku antara lain: "Esai-esai Ekonomi Politik" (1983), "Transformasi Pertanian, Industrialisasi dan kesempatan kerja" (1985), "Perekonomian Indonesia: Pertumbuhan dan Krisis" (1986), "Perspektif Deklarasi Makkah: Menuju Ekonomi Islam" (1987), "Etika Bisnis dan Manajemen" (1990), "Masyarakat Madani: Agama, Kelas Menengah dan Perubahan Sosial" (1999), dan "Islam dan Transformasi Sosial-Ekonomi" (1999). Selain itu beliau juga banyak menulis tema-tema yang kemudian muncul di beberapa Jurnal maupun majalah.

Dapat dikatakan bahwa karya Dawam sejak akhir 1960-an berusaha mengungkap situasi politik yang tidak menguntungkan. Dalam konteks ini, menurutnya ada tiga mazhab pemikiran yang berkembang. Pertama, pembaharuan keagamaan/teologis yang memfokuskan diri pada pencarian dasar-dasar teologi baru yang memungkinkan terciptanya sintesa yang memungkinkan antara Islam dan negara, terutama dilihat dari sudut hubungan politik. Kedua, pembaharuan politik/birokrasi yang bertujuan untuk menjembatani hubungan antara Islam dan pemerintah, sehingga kecurigaan-kecurigaan politik dan ideologis bisa dikikis, paling tidak

\footnotetext{
${ }^{36}$ Ibid., hlm., xii-xiii

37 M. Dawam Rahardjo, Masyarakat Madani ..., Op.Cit., hlm,, ix-x.
} 
dikurangi. Ketiga, aliran transformasi sosial ekonomi dan kemasyarakatan. Perhatian utama kelompok ini adalah melakukan pemberdayaan sosial ekonomi dan politik masyarakat bawah, baik yang berada di pedesaan maupun perkotaan. Dawam Rahardjo, merupakan salah satu pionir dalam gerakan ini. ${ }^{38}$

Menempatkan dakwah transformasi sosial-ekonomi dan kemasyarakatan sebagai prioritas perhatiannya. Hal pertama yang dilakukan adalah mengembangkan program industri kecil sesuatu yang dianggapnya rnempunyai makna strategis ekonomis untuk diperkenalkan pada masyarakat bawah. Di situ secara inheren juga tercakup semangat perlunya meningkatkan daya kewirausahaan rakyat, yang relatif monumental adalah agenda pengembangan masyarakat melalui pondok pesantren. Ia melihat lembaga pendidikan tradisional Islam ini jumlahnya banyak. Melalui serangkaian program pemberdayaan, tak pelak pesantren akan mampu berperan sebagai agen of change bagi masyarakat. Ini diyakini akan mempunyai dampak sosial ekonomi yang cukup berarti di tingkat akar rumput.

Dalam mencapai keberhasilan, menurut Dawam hal ini tidak bisa dilakukan sendirian. Keterlibatan pemerintah, yang memang mempunyai networking birokrasi dan program pembangunan yang sebanding merupakan kebutuhan. Maka ia berusaha memasukkan program pembangunan masyarakat melalui pesantren ini ke dalam agenda resmi Departemen Agama, pada waktu itu. Meskipun demikian, itu semua diagendakan bukan dalam konteks persaingan antara masyarakat dan negara. Apalagi diwarnai oleh kebencian-kebencian tidak kontributif terhadap negara sesuatu yang sering dituduhkan negara Orde Baru kepada kalangan intelektual-aktivis. Di sinilah letak sinerginya pendekatan dan proyek yang dipilah dengan agenda pembaharuan keagamaan/ teologis di satu pihak, dan pembaharuan politik/birokratis di pihak lain. Masingmasing bekerja sesuai dengan bidangnya, untuk mencapai sesuatu yang telah digariskan.

Berikut beberapa pemahaman Dawam Rahardjo kaitannya dengan dakwah sosial ekonomi;

\section{Ekonomi Islam}

Ada tiga kemungkinan penafsiran tentang istilah ekonomi Islam. Pertama yang dimaksud adalah ekonomi yang berdasarkan nilai-nilai atau

38Disarikan dan Bahtiar Effendi, "M, Dawam Rahardjo dan Pembaharuan Pemikiran Islam: Perspektif Transformasi Sosial Ekonomi", dalam Prof. Dawam Rahardjo, Islam dan Transformasi ......, Op.Cit., hlm. xiv-xv. 
ajaran Islam. Kalau ini yang dimaksud, maka akan timbul kesan bahwa ajaran Islam itu mempunyai pengertian yang tersendiri mengenai apa itu ekonomi. Hal ini tentu akan diikuti dengan pertanyaan, apakah yang dimaksud dengan ekonomi itu menurut ajaran Islam? ${ }^{39}$. Kedua yang dimaksud adalah sistem ekonomi Islam, sistem menyangkut pengaturan, yaitu pengaturan kegiatan ekonomi dalam suatu masyarakat atau negara berdasarkan suatu cara atau metode tertentu. Oleh sebab itu sistem bersifat normatif. Ketiga adalah sebagai perekonomian Islam atau mungkin lebih tepat perekonomian dunia Islam, Pemikiran seperti ini berkembang dan sikap pragmatis, sebagaimana dilakukan oleh organisasi Islam OKI. Sambil mengembangkan tentang teori-teori ekonomi Islam, maka OKI mengambil prakarsa untuk memajukan perekonomian masyarakat yang beragama Islam. Upaya dilakukan dalam bidang perdagangan antara negara-negara Islam penanaman modal dan terutama sangat menonjol dengan mendirikan bank pembangunan Islam. ${ }^{40}$

Ekonomi pada hakekatnya adalah segala aktivitas yang berkaitan dengan produksi dan distribusi serta konsumsi di antara orang-orang. Tetapi apa yang diproduksi dan didistribusikan? Pengertian umum kita adalah produksi dan distribusi barang dan jasa yang bersifat material. Pertanyaan yang timbul adalah apakah pengertian ekonomi ini juga terbatas oleh pengertian kekayaan material. Tentu saja seorang muslim bisa berkomentar bahwa ajaran Islam itu tidak hanya menyangkut soalsoal duniawi, tetapi juga ukhrowi, tidak hanya material tetapi juga spiritual. Apakah definisi kita mengenai ekonomi ingin mengubah sasaran kegiatan ekonomi yang bagi muslim mencakup juga produksi spiritual atau rohaniah karena kebutuhan manusia itu menurut Islam tidak hanya merupakan kebutuhan material. ${ }^{41}$ Namun yang jelas dalam ajaran Islam terdapat doktrin-doktrin yang perlu dikembangkan berkaitan dengan kehidupan ekonomi yakni ibadah, akhirat, dan amal shaleh. ${ }^{42}$

Kalau pengertian itu dijadikan acuan, maka Islam bisa memberikan komentar tentang apa seharusnya tujuan aktivitas itu, yang tentunya tercermin dalam tujuan hidup muslim itu sendiri yang tidak hanya mencakup segi-segi material, tetapi juga spiritual.

Ilmu ekonomi Islam sebenarnya sama saja dengan ilmu ekonomi umumnya, yaitu menyelidiki perilaku manusia dalam kegiatan produksi,

${ }^{39}$ Dawam Rahardjo, Islam dan Transformasi Op.Cit., hlm,, 3.

${ }^{40}$ Ibid, hlm., 4.

41 Disarikan dan Ibid., hlm, 5-6.

42 M. Dawam Rahardjo, Etika Ekonomi dan Manajemen, (Yogyakarta: Tiara Wacana, I 990) hlm., 123. 
distribusi dan konsumsi yang menyangkut pilihan terhadap sumberdaya yang sifatnya langka dan alokasi sumberdaya tersebut guna memenuhi kebutuhan manusia. Dalam Islam, tujuan kegiatan ekonomi hanyalah merupakan target untuk mencapai tujuan yang lebih tinggi yaitu kebahagiaan hidup di dunia maupun di akhirat, dengan melakukan ibadah kepada Allah. Ilmu ekonomi Islam memperhatikan dan menerapkan syari'ah dalam perilaku ekonomi dan dalam pembentukan sistem ekonomi.

Berbeda dengan pandangan humanisme bahwa manusia itu adalah ukuran dari segalanya, pusat dan arti penting (significance) dan wadah dari segala kebajikan, maka Islam menempatkan kemanusiaan sebagai sekunder dari nilai tauhid, konsep ketuhanan Yang Maha Esa. Dengan demikian tuhan yang maha esa adalah sumber yang mendasar dan nilai kemanusiaan. Karena itulah yang paling berhak menilai dan menempatkan manusia di antara semua makhluk-Nya. Dalam penilaian Allah, manusia adalah mahkota ciptaan-Nya, dan manusia oleh Allah didesain sebagai sebaik-baik ciptaan. ${ }^{43}$

Implikasinya dalam kebijakan ekonomi yang lebih sesuai dengan ajaran kemanusiaan Islam adalah kebijakan yang lebih mendorong setiap individu untuk mencari rizki, dengan begitu ia dapat setiap manusia muslim dapat memuliakan hidup dengan mengolah sumber daya alam. ${ }^{44}$

\section{Masyarakat Utama}

Konsep "masyarakat utama" adalah masyarakat yang unggul di segala bidang, terutama akhlak anggota masyarakatnya dan unggul dari segi politik, ekonomi dan budaya. Konsep masyarakat utama ini sebenarnya merupakan pemikiran futuristik, yang sejalan dengan firman Allah bahwa masa depan itu harus lebih baik dari masa kini. ${ }^{45}$ Hal ini termaktub dalam al-qur'an surat Al-Hasyr; ayat 18 "Hai orang-orang yang beriman hendaklah kalian melihat masa depan..."

Secara substantif, masyarakat utama itu oleh al-Qur'an sudah dijelaskan, dengan cara menyebut ciri-cirinya, yakni: a) menegakkan yang baik (ma'ruf), b) mencegah yang buruk atau jahat (munkar) dan, c) Beriman kepada Allah (tu 'minuna billah) ${ }^{46}$ Dalam kehidupan masyarakat mekanisme amar ma'ruf dan nahi munkar itu sebenarnya tercakup ke

43 M. Dawam Rahardjo, Etika Ekonomi dan Manajemen, (Yogyakarta: Tiara Wacana, I 990) hlm., 123.

${ }^{44}$ Dawam Rahardjo, Islam dan Transformasi Op.Cit., hlm., 250

${ }^{45}$ Ibid, hlm. 344

46 Ibid, hlm. 343 
dalam aturan atau peraturan-peraturan, tata hukum dan konstitusi, bahkan juga rencana-rencana pembangunan yang bisa menciptakan kebaikan dan mencegah keburukan, seperti kemiskinan dan keterbelakangan. Dengan kata lain mekanisme tersebut dapat dilembagakan ke dalam suatu negara hukum atau masyarakat hukum. ${ }^{47}$

A1-Qur'an sebenarnya telah memberi penjelasan tentang khairu ummah yang dimaksud, yakni kumpulan orang yang memiliki kesamaan budaya (a group of people who share a common culture). Budaya itu adalah orientasi kepada al khair, memiliki mekanisme amar ma'ruf nahi munkar, aturan, tatanan atau .48

Dalam Islam citra masyarakat utama telah diproyeksikan secara futuristik sebagai masyarakat masa depan yang telah digambarkan dalam istilah baldatun tayyibah wa rabbun ghafur (QS Saba': 15). Gambaran masyarakat utama juga dapat dilihat dalam al-Qur'an surat al-Baqarah ayat 126. Dalam ayat ditemui dua konsep, yaitu, keamanan (balada amina) dan kemakmuran. Dari ayat-ayat tersebut didapatkan telah memperoleh gambaran tiga konsep yang dapat dicirikan pada masyarakat utama, yakni: 1) keamanan, 2) kemakmuran, 3) keimanan. Kondisi ini adalah sesuatu yang dituju oleh suruhan amar ma'ruf, menegakkan kebaikan. Dalam kaitannya dengan dimensi ekonomi, kemakmuran di atas dapat dicapai dengan berbagai cara, yang terpenting adalah mencari rizki yang halal. Di samping itu terdapat anjuran nahi munkar, dalam dimensi sosial ekonomi, yang munkar itu di antaranya adalah perbudakan dan kemiskinan dan berbuat kerusakan di bumi, memakan barang-barang yang haram, memalsukan takaran dan timbangan, memakan riba, boros dan kikir, loba dan tamak, dan mengedepankan harta dan kekayaan.

Berdasarkan uraian di atas menjadi jelas bahwa konsep masyarakat utama dalam Islam ialah masyarakat yang memiliki sistem kelembagaan untuk mencapai kebajikan (al-khair), melaksanakan yang baik (amar ma'ruf), mencegah yang buruk atau jahat (nahi munkar), serta menegakkan dan memelihara iman (tu'minu billah).

\section{Zakat dan Pengembangan Swadaya Umat Islam}

Zakat merupakan salah satu bentuk pengabdian kepada Allah swt. dalam bentuk pembelanjaan (al infaq) harta benda. Dalam teologi kontemporer disebut sebagai ibadah yang mengandung dimensi sosial. 122.

47 M. Dawam Rahardjo, Masyarakat Madani: Agama, Kelas Menengah... ,Op.cit,, hlm.,

48 Ibid. 
Zakat juga merupakan manifestasi hubungan antara si kaya dengan si miskin dengan cara mentransfer harta dari yang kaya untuk diberikan pada yang miskin. Dalam pengertian sehari-hari yang hidup di lingkungan umat Islam, dan tentu saja bersumber dari hukum fikih, terdapat definisi yang membedakan tiga istilah itu. "Zakat" adalah shadaqah yang sifatnya wajib, berdasarkan ketentuan nishab dan haul dan diberikan kepada mereka yang berhak menerima, yakni 8 asnaf (golongan) seperti yang tercantum dalam surat at Taubah: 60, sedangkan "shadaqah" itu sendiri adalah pemberian yang sifatnya sukarela, tanpa ada ketentuan mengenai nishab, haul dan asnaf walaupun pada umumnya sasarannya berpedoman pada ayat 60 surat al Taubah di atas.

Dalam praktek, jumlah sadaqah itu kecil dan diberikan kepada fakirmiskin atau untuk sekedar membantu seseorang, diminta atau diberikan. Baik zakat maupun sadaqah, keduanya termasuk kedalam pengertian infaq, yaitu bagian yang "dibelanjakan" dan harta atau kekayaan seseorang untuk kemaslahatan umum atau membantu yang lemah. Namun dalam pengertian sehari-hari, infaq itu adalah sesuatu yang dikeluarkan di luar atau sebagai tambahan dari zakat, yang sifatnya sukarela. Pada umumnya, jumlahnya besar karena dikeluarkan oleh orang yang berada. ${ }^{49}$

Bagi Dawam Rahardjo pelaksanaan zakat yang dilaksanakan secara konvensional yaitu yang diberikan dalam bentuk pemberian langsung dari muzakki (wajib zakat) kepada mustahik (yang berhak) atau yang lazim disebut bentuk hibah. Distribusi zakat model demikian ini memiliki dampak yang negatif maupun positif, segi negatifnya adalah bahwa selain jumlahnya tidak besar, penerimanya cenderung untuk mempergunakannya bagi keperluan konsumtif. Zakat seperti ini tidak memberikan dampak pengentasan kemiskinan. ${ }^{50}$

Dengan demikian sudah saatnya pelaksanaan zakat dilakukan dengan menggunakan pengembangan manajemen zakat, sehingga fungsi zakat dapat dirasakan oleh masyarakat secara merata dan tidak hanya sekali waktu. Hal ini bisa dilaksanakan dengan pendistribusian dalam bentuk pinjaman, baik dengan sistem bagi hasil atau tanpa bunga. Zakat yang model demikian ini bukan merupakan hal baru lagi, sebab Badan Amil Zakat, infaq dan shadaqah (BAZIS) di beberapa daerah misalnya DKI Jakarta dan Jawa Barat telah mempraktekkannya, yaitu dengan mengalokasikan sekitar $10 \%$ hingga $25 \%$ dari zakat yang dikumpulkannya sebagai dana pinjaman. ${ }^{51}$

\footnotetext{
${ }^{49} \mathrm{Ibid}, \mathrm{hlm}, 475$

${ }^{50} \mathrm{Ibid}$., hlm. 465.

51 Ibid hlm.468
} 
Sistem bagi hasil dari sebuah bentuk zakat yang dipinjamkan adalah alternatif yang mungkin lebih bisa diterima, karena sistem yang demikian, menurut pendapat dewasa ini, sesuai dengan ketentuan syari'ah. Model pengembangan manajemen zakat diatas, nampaknya dapat merangsang timbulnya model baru bagi pendistribusian zakat yang lebih baik lagi, yaitu distribusi zakat dengan cara kredit. Dengan cara ini, maka yang diberikan adalah "pancing" dan bukan "ikan". Sungguhpun demikian pola hibah masih bisa dimanfaatkan juga. Model ini diharapkan agar zakat benarbenar dapat memberikan dampak signifikan dalam program pengentasan kemiskinan. Maka diperlukan peraturan penyelenggaraan zakat secara nasional supaya dapat lebih terorganisir dan juga model pendistribusian yang dapat merangsang mustahik untuk memanfaatkan dana zakat secara produktif, dan ini berarti proses manajemen zakat.

\section{Etos Kerja dalam Islam}

Manusia tidak bisa lepas dari pekerjaan. Manusia diciptakan Tuhan bukan saja sebagai hiasan pekerjaan tetapi sebagai suatu ciptaan yang diberi tugas, dan tugasnya ialah memelihara ciptaan ini dengan pekerjaan. Dengan demikian pekerjaan merupakan salah satu tugas Illahi, yang merupakan suatu kewajiban dan suatu hak. Ketika berbicara mengenai etos kerja, maka sebetulnya di situ tersimpan suatu asumsi, bahwa peranan manusia sebagai individu itu sangat menentukan, artinya kesadaran manusia atau nilai-nilai budaya yang dianut oleh manusia itu sangat menentukan. Jadi proses pembangunan ekonomi, etos kerjalah yang menjiwai dan menuntun langkah-langkah atau perilaku manusia. Teori ini tentu dibantah oleh paham struktural yang mengatakan sebaliknya. Kesadaran itu dibentuk oleh kondisi, oleh lingkungan dan sebagainya.

Tapi dalam proses dialektika, akhirnya terjadi suatu sintesa, bahwa kondisi struktural itu memungkinkan, atau membuat mungkin suatu pembangunan. Tetapi faktor kultural itulah yang pada akhirnya menentukan, apakah pembangunan itu mungkin atau tidak mungkin. Hal ini merupakan suatu perbaikan dari teori mental dan struktural sekaligus. Walaupun demikian teori ini termasuk ke dalam paham cultural determinism. ${ }^{52}$

Tuduhan lain misalnya datang dari golongan Marxis yang mengatakan bahwa teori modernisasi secara keseluruhan mengandung pemikiran yang etnosentris Eropa Barat, karena yang dianggap sebagai

52 Dawam Rahardjo, Islam dan Transformasi, Op.Cit, hlm, 250. 
nilai tersebut adalah yang terkandung dalam ide Westernisasi versi Barat. Sedangkan yang disebut sikap mental, ciri-ciri nilai atau nilai kultural suatu masyarakat yang dianggap menghambat pembangunan adalah sikap mental atau nilai-nilai ketimuran (tradisional). Jadi nilai-nilai tradisional itu harus dilenyapkan dan di ganti dengan nilai-nilai yang lebih modern, yang dalam hal ini adalah nilai-nilai yang sudah berkembang di Barat. Hal inilah yang ditolak oleh golongan marxis karena nilai-nilai di Barat itu dikondisikan di dalam sejarah atau dibentuk oleh suatu kondisi tertentu, yaitu struktur masyarakat atau modal produksi kapitalis. Jadi tidak ada apa yang disebut nilai-nilai universal yang berlaku antuk semua jaman, setiap waktu, dan setiap tempat. Nilai-nilai pandang atau sikap itu ditentukan oleh kondisi tertentu dan khususnya di sini adalah kondisi ekonomi. ${ }^{53}$

Dalam konteks agama Islam, Dawam melihat ada beberapa hal yang menentukan sikap mental penganutnya, antara lain; adanya kecenderungan bahwa umat Islam itu bersikap pasrah atau menyerah kepada nasib, atau takdir Tuhan paham Jabariyah, bahwa umat Islam lebih banyak berorientasi kepada hal-hal yang bersifat akhirat, adanya faham zuhud atau hidup sederhana, adanya faham tawasul atau perantara dalam berhubungan dengan Tuhan.

Berkaitan dengan beberapa hal di atas, maka Dawam memberikan ulasannya sebagai berikut. Pertama, mengenai konsep pasrah kepada nasib. Paham ini ternyata menimbulkan sikap mental yang tangguh. Pandangan Dawam ini ternyata menganut pemikiran Max Weber yang mengatakan bahwa paham calvinisme -yang mirip dengan paham jabariyah dalam Islam - merupakan hal yang dianggap bertanggung jawab terhadap perkembangan kapitalisme pada abad ke-16. Ia mengatakan bahwa karena kita tidak tahu takdir kita sendiri, maka kita masing-masing berusaha mendapatkan takdir tersebut dan kemudian ada semacam keterpanggilan terhadap kita untuk melakukan hal-hal yang istimewa, yang bersifat mengabdi. Dan sikap mengabdi itu tumbuh sikap sederhana, sikap jujur dan semua itu dilakukan untuk mendapatkan keselamatan dari Tuhan. ${ }^{54}$

Kedua, mengenai orientasi pada akhirat. Dalam pandangan Dawam, kepercayaan kepada kehidupan akhirat itu dapat menimbulkan suatu sikap tertentu, yaitu sikap untuk bertanggung jawab. Kalau seseorang tidak percaya kepada akhirat, artinya perbuatan orang tersebut tidak akan dibalas, tidak ada pahala dan dosa, dan sebagainya. Lalu tidak ada motivasi

53 Ibid, hlm, 250.

${ }^{54}$ Ibid, hlm, 264 
seseorang untuk berbuat baik, karena berbuat benar atau salah, sama saja. Ketiga, faham zuhud atau hidup sederhana. Hidup sederhana dapat menimbulkan sikap hemat, tidak boros, sehingga mempunyai tabungan dan kemudian diinvestasikan lagi. Di samping tidak ingin berfoya-foya, ia juga ingin bersikap jujur. Sikap julur itu juga menimbulkan etos, katakanlah etos mempertahankan kualitas dan tidak menipu kualitas dalam produk yang dibuat. 55

\section{G. Penutup}

\section{Kesimpulan}

Dari uraian tentang pendapat dan pandangan Dawam tentang dakwah sosial ekonomi dan hal-hal yang melingkupinya, berikut ini disimpulkan beberapa hal sebagai berikut:

a. Dakwah ekonomi fokus terhadap sistem ekonomi yang lebih tepat untuk masyarakat Indonesia yang tidak lain sistem ekonomi yang berbasis ke-Islaman, kendatipun berbenturan dengan landasan konstitusional kita Pancasila. Karena itu diperlukan hubungan yang harmonis antara Islam dan Negara bahwa Ideologi Pancasila harus didudukkan secara tepat oleh umat Muslim.

b. Dakwah yang menyerukan bahwa Islam dijadikan sebagai landasan amal yang berarti kreatifitas/kerja (peningkatan etos kerja), yang dimulai dengan kesadran akan pentingnya arti tanggung jawab kepada masa depan bangsa dan Negara.

c. Dalam hubungannya dengan aktifitas Dakwah Islam, maka apa yang dirumuskan Dawam Rahardjo merupakan penjabarannya tentang nilainilai ke-Islaman untuk disosialisakan kepada publik sejalan dengan poses dakwah yang merupakan agen perubahan.

\section{Saran-saran}

Adapun saran-sarannya penulis melihat sebagai berikut :

a. Pandangan Dawam Rahardjo seputar dakwah sosial ekonomi merupakan kontribusi bagi bengembangan kegiatan dakwah Islam masa depan, namun dalam pelaksanaannya ditemukan banyak hambatan dengan berbenturannya akan kondisi sosial politik bangsa Indonesia dengan kemajemukannya, dimana pelaksanaan system

${ }^{55} \mathrm{Ibid}, \mathrm{hlm}, 265-266$. 
ekonomi yang berlandaskan ke-Islaman tidak sepenuhnya dapat terwujud, untuk itu pandangan Dawam Rahardjo hendaknya dijadikan landasan kehidupan masyarakat, khususnya umat Muslim, bukan sebagai landasan Ideologi terlebih Ideologi Negara.

b. Yang berhubungan dengan pilihan bahwa Islam tidak dapat dijadikan Ideologi Negara, namun bisa dijadikan falsafah hidup umat Muslim, tentunya hal ini tidak akan dapat diterima sepenuhnya oleh sekelompok Muslim keras, Karenanya setiap warga Negara hendaknya mampu memahami apa yang sebenarnya terjadi di Indonesia, karena Indonesia merupakan Negara yang majemuk/plural .

\section{Kata Penutup}

Demikian tulisan sederhana ini semoga tepat sasaran dan bermanfaat, penulis menyadari bahwa sajiannya masih jauh dari sempurna, utuk itu saran dan kritik yang positif dari pembaca sangat diharapkan penulis. Penulis juga berharap kiranya tulisan ini sebagai salah satu jalan berdakwah kepada Allah swt amin Ya Rabbal Alamien . 


\section{DAFTAR PUSTAKA}

Ahmad, Amrullah, (Ed), Dakwah Islam dan Perubahan Sosial, (Yogyakarta: PLP2M, 1983).

Amrullah, Prospek Dakwah Islam dalam Masyarakat informasi Abad ke 21, (Bandung: Remaja Rosdakarya, 1988).

Al-Chaidar, Reformasi Prematur: Jawaban Islam terhadap Reformasi Total, (Jakarta: Darul Falah, 1999), cet. V.

Ali, A. Mukti, Beberapa Persoalan Agama Dewasa ini, (Jakarta: Rajawali Press, 1985).

Anshari, M. Hafi, Pemahaman dan Pengamalan Dakwah, (Surabaya: Al Ikhlas, 1993).

Basyir, K.H. Ahmad Azhar, Refleksi Alas Persoalan KeIslaman: Seputar Filsafat, Hukum, Politik dan Ekonomi, (Bandung: Mizan, 1989).

Budhy Munawar Rachman, (ed.), Kontekstualisasi Doktrin Islam dalam Sejarah, (Jakarta: Paramadina, 1994).

Buletin Ekonomi Moneter dan Perbankan, Volume 2, Nomor 1, Juni 1999.

Damami, Muhammad, Tasawuf Positif dalam Pemikiran Hamka, (Yogyakarta: Fajar pustaka Baru, 2000)

Departemen Agama RI., Al-Qur'an dan Terjemahannya, (Surabaya: CV. Jaya Sakti, 1989).

Departemen P\&K, Kamus Besar Bahasa Indonesia, (Jakarta: Balai Pustaka 1997).

Donohue, John J. dan John 1. Esposito, "Islam Pembaharuan", dalam Khursyid Ahmad, Islam dan Tantangan Pembangunan Ekonomi, (Yogyakarta: PT Raja Grafindo Persada., 1993), Cet. ifi.

Effendy, Bahtiar, Islam dan Negara Transformasi Pemikiran dan Praktik Politik Islam di Indonesia (Jakarta: PT. Grafindo Persada, 1998).

Hasan, Rifa'i dan Amrullah Achmad (ed.), Perspektif Islam dalam Pembangunan Bangsa, (Yogyakarta: PLP2M, 1987), cet. I.

Ilyas, Yunahar (ed.), Muhammadiyah dan NU, (Yogyakarta: Aditya Media, 1994), Cet. 11.

Jurnal Ulumul Qur'an, vol. III No: 4 Tahun 1992. 
Kartono, Kartini, Pengantar Metodologi Riset Sosial, (Bandung: Mizan, 1990).

Kuntowidjoyo, Paradigma Islam Interpretasi Untuk Aksi, (Bandung: Mizan, 1991), CetI.

M. Arifin, Psikologi Dakwah, (Jakarta: Bumi Aksara, 1993), Cet II

Muhadjir, H. Noeng, Metodologi Penelitian Kualitatif, Edisi III (Yogyakarta: Rake Sarasin, 1996)

Mulkhan, Abdul Munir, Ideologisasi Gerakan Dakwah Episode kehidupan M. Natsir dan Azhar Basyir, (Yogyakarta: Sipress, 1996), Cet. I.

Nasution, Harun, Islam Rasional: Gagasan dan Pemikiran Prof Dr. Harun Nasution, Cet. IV, (Bandung: Mizan, 1996).

Rahardjo, Dawam, Islam dan Transformasi Sosial Ekonomi, (Yogyakarta: Pustaka Pelajar, 1999), Cet. 1.

, M. Dawam, Intelektual, Intelegensia dan Perilaku Politik Bangsa: Risalah Cendekiawan Muslim (Bandung: Mizan, 1999).

, M. Dawam, Masyarakat Madani: Agama, Kelas Menengah dan Perubahan Sosial, (Jakarta: LP3ES,1999) cet. I.

M. Dawam, Etika Ekonomi dan Manajemen, (Yogyakarta: Tiara Wacana, 1990), hlm., 123.

Rais, Amien, Islam dan Pembaharuan Ensiklopedi Masalah-Masalah, (Yogyakarta: PT Raja Grafindo Press) Cet. III.

Rais, M. Amien (ed,), Islam di Indonesia: Suatu Renungan Mengaca Diri, (Jakarta: PT. Raja Grafindo Persada, 1996), cet.I.

Sanwar, Aminuddin, "Pengantar Ilmu Dakwah", (Semarang: Diktat Fakultas Dakwah IAIN Walisongo, 1987).

M. Aminuddin, Ilmu Dakwah Suatu Pengantar Studi, (Semarang: Fakultas Dakwah IAIN Walisongo, 1997).

Sasono, Adi, Dakwah Pembangunan, Permasalahan dan Alternatif, (Yogyakarta: PLP2M, 1985).

Soekanto, Soerjono, Teori Sosiologi Tentang perubahan Sosial, (Jakarta: Ghalia Indonesia, cet.1,1983).

Soerjono, Sosiologi Suatu Pengantar, (Jakarta: CV. Rajawali, 1982). 
Soerjono, Sosiologi Suatu Pengantar, (Jakarta: Rajawali, 1985), Cet $\mathrm{V}$.

Syaijsii al-Islam MuhyiddIn, Riyadh al-Shalihin, Dar al-Ihya, (Indonesia, t.th.).

Syukir, Asmuni, Dasar-Dasar Strategi Dakwah Islam, (Surabaya: A1-Ikhlas, 1993).

Tasmara, Toto, Etos Kerja Pribadi Muslim, (Yogyakarta: PT. Dana Bhakti Wakaf, 1995), Cet. 11.

Wahjono, Padmo, Transformasi Nilai-nilai Ideologi Bangsa, (Jakarta: Mimbar BP-7 tahun III 1986.

Ya'qub, Hamzah, Publisistik Islam Teknik Dakwah dan Leadership, (Yogyakarta: Bulan Bintang, 1992). 